\title{
Dari Asia Tenggara Hingga Sulawesi Barat: Perkembangan Penyalahgunaan Narkoba di Sulawesi Barat
}

\author{
Asma Amin ${ }^{1}$, Farhanuddin ${ }^{2}$, Muh. Nasir Badu, Darwis ${ }^{4}$ \\ ${ }^{1}$ Universitas Sulawesi Barat; ${ }^{2}$ Universitas Sulawesi Barat; \\ ${ }^{3}$ Universitas Hasanuddin; ${ }^{4}$ Universitas Hasanuddin \\ Email : asmaamin.hi06@gmail.com
}

\begin{abstract}
ABSTRAK
Konsep keamanan telah mengalami redefenisi yang dikenal dengan isu-isu keamanan non tradisional (non traditional security), dimana persoalan keamanan tidak hanya terkait dengan masalah militer semata. Salah satu persoalan non tradisional security yang berkembang di Asia Tenggara adalah masalah drugs trafficking. Drugs trafficking akan berdampak secara spesifik terhadap human security dan secara umum berpengaruh terhadap stabilitas regional kawasan Asia tenggara, terhadap negara dan juga merambah sampai ke daerah (pedesaan), termasuk untuk wilayah Sulawesi Barat. Untuk itu, dengan menggunakan metode kualitatif dan menekankan penggalian data melalui sumber-sumber tertulis dan wawancara dengan narasumber, penelitian ini akan menelusuri masuknya narkoba dari Asia Tenggara hingga ke Sulawesi Barat, perkembangan penyalahgunaan narkoba, serta upaya yang dilakukan dalam menangani masalah tersebut. Penelitian ini menunjukkan bahwa narkoba yang beredar di Sulawesi Barat berasal dari luar wilayah Sulawesi Barat. Angka penyalahgunaan tergolong tinggi dimana salah satu faktor penyebabnya adalah keterlibatan petugas dan perubahan gaya hidup modern yang didukung oleh tingkat kesejahteraan penduduk yang semakin membaik di tengah penataan kota sebagai sebuah provinsi baru.
\end{abstract}

Kata kunci: Drugs trafficking, transnational crime, human security, keamanan non tradisional, Sulawesi Barat 


\section{PENDAHULUAN}

Konsep keamanan telah mengalami redefenisi yang dikenal dengan isu-isu keamanan non tradisional (non traditional security), dimana konsepsi keamanan saat ini tidak lagi hanya berbicara dalam perspektif kedaulatan nasional dan kekuatan militer saja. Isu-isu globalisasi, demokratisasi, penegakan HAM, kejahatan lintas batas dan berbagai isu lainnya telah memperluas cara pandang manusia dalam melihat kompleksitas ancaman yang ada, baik di dunia internasional, regional, ditingkat negara hingga ke pelosok desa. Salah satu persoalan non tradisional security yang terus menjadi perhatian adalah masalah kejahatan transnasional drugs trafficking.

Persoalan drugs trafficking di wilayah Asia Tenggara, merupakan hal yang sangat urgent, hal ini disebabkan karena kawasan ini, selain sebagai produsen, juga merupakan konsumen besar dengan pangsa pasar sekitar kurang lebih 500 juta jiwa. Peta produsen utama di wilayah Asia Tenggara adalah wilayah golden triangle atau dikenal dengan segitiga emas. Wilayah ini terdiri dari Thailand Utara, Myammar Timur dan Laos Barat dan merupakan salah satu dari dua kawasan yang dikenal sebagai pusat penanaman, produksi dan perdagangan opium dunia. Selama tahun 1970-an dan 1980-an, kawasan ini dianggap sebagai produsen opium terbesar di dunia. Selama tahun 1980-an, Myammar merupakan penghasil opium terbesar, mencapai 700 metrik ton per tahun antara tahun 1981-1987. Diperkirakan pada akhir 1990-an, 2/3 opium poppies dunia (yang kemudian diolah menjadi heroin) ditanam di Asia Tenggara (Roza, 2012:6).

Dari kawasan golden Triangle, narkoba ini kemudian dibawa ke berbagai wilayah di dalam kawasan Asia Tenggara bahkan di luar kawasan. Persoalannya kemudian, penyebaran narkoba bukan lagi menyentuh wilayah perkotaan yang hedon, modern atau metropolis, namun telah menyebar hingga ke polosok-pelosok seperti pedesaan. Salah satu wilayah yang mendapatkan implikasi langsung dari penyebaran narkoba adalah wilayah Sulawesi Barat.

Untuk itu, tulisan ini bertujuan untuk menganalisis bagaimana masuknya narkoba di Sulawesi Barat. Bagaimana pola penyebaran dan perkembangan narkoba di Sulawesi Barat, serta upaya pemerintah di Sulawesi Barat dalam mengatasi masalah tersebut.

\section{METODE DAN KERANGKA KONSEP}

Metode penelitian yang digunakan dalam penelitian ini adalah metode kualitatif. Metode kualitatif adalah metode penelitian ilmu sosial yang bersifat deskriptif dan berusaha untuk menginterpretasikan gejala yang terjadi pada sebuah konteks sosial. Penelitian ini menekankan penggalian data secara mendalam melalui sumber-sumber yang tertulis dan wawancara yang mendalam dengan narasumber. Pengumpulan data untuk penelitian ini dilakukan melalui dua cara, yaitu :

1. Data primer, data yang dikumpulkan melalui wawancara dengan orang/pihak yang memiliki authority di bidang ini.

2. Data sekunder merupakan data yang diperoleh dari hasil tulisan orang lain yang telah dipublikasikan, seperti buku, jurnal, dokumen, artikel, media cetak dan 
online serta laporan dari berbagai sumber yang relevan dengan hasil penelitian yang akan disusun. Data yang diperoleh kemudian diakumulasikan dan dikomparasikan sehingga dapat diperoleh generalisasi terhadap data tersebut.

Penulis menggunakan teknik analisis kualitatif dalam menganalisis data yang ada dengan maksud untuk memberikan gambaran perkembangan penyalahgunaan narkoba di Sulawesi Barat dan dampaknya terhadap human security.

Dalam penelitian ini, perlu dijelaskan beberapa konsep yang penting untuk memahamii tulisan ini, antara lain :

\section{Kejahatan Transnasional (Transnational Crime)}

Untuk menggambarkan istilah kejahatan transnasional secara spesifik, diperlukan pembatasan defenisi bagi istilah tersebut. Menurut United Nations Convention on Transnational Organized Crime (2000), yang dimaksudkan dengan istilah kejahatan transnasional yaitu tindakan kejahatan yang melibatkan setidaknya dua negara. Maksud dari keterlibatan dua negara tidak harus bersifat langsung, namun secara lebih detail dijabarkan bahwa yang termasuk kategori ini apabila (1) suatu tindakan kriminal dilakukan di lebih dari satu negara; (2) jika persiapan, perencanaan, pengarahan dan pengawasan suatu tindakan kriminal dilakukan di negara A tetapi tindakannya dilakukan di negara B; (3) melibatkan organized criminal group dimana kejahatan dilakukan di lebih satu negara dan (4) jika suatu tindakan kriminal dilakukan di satu negara namun dampaknya terasa sampai ke setidaknya satu negara lain.

Secara lebih spesifik, PBB kemudian membagi kejahatan transnasional ke dalam 18 kategori, dimana dalam kategori kejahatan tersebut umumnya melibatkan aktor dan aktivitas di lebih dari satu negara. Hal ini termasuk pencucian uang; terorisme; pencurian benda-benda seni dan budaya; pencurian kekayaan intelektual; penjualan senjata ilegal; pembajakan pesawat terbang; perombakan di laut; penipuan asuransi; kejahatan lingkungan; kejahatan komputer; perdagangan manusia; perdagangan bagian tubuh manusia; penjualan obat-obatan terlarang; penipuan kepailitan; penyusupan ke bisnis pihak lain (infiltrasi bisnis), korupsi dan penyuapan petugas publik atau pihak tertentu (Paripurna, 2008:8).

Aktor yang terlibat dalam kejahatan transnasional ini tidak selalu berkaitan dengan aktor negara, namun telah meluas sehingga dapat melibatkan aktor seperti individu, kelompok atau organisasi. Motif dan latar belakang dari kejahatan transnasionalpun multidimensional, menyangkut bidang politik, ekonomi, sosial, budaya dan lain-lain. Peran aktorpun tidak harus sebagai pelaku langsung, namun termasuk yang menjadi pemikir, pemberi dana (sponsor) atau yang memberi arahan atau perintah. Hal inilah yang menyebabkan kejahatan lintas batas negara dewasa ini dipandang sebagai salah satu ancaman serius terhadap keamanan global. Ancaman baru ini bersifat multidimensional dan umumnya terorganisir dengan sangat baik dan membentuk jaringan. Apabila penanggulangannya kurang tepat maka ancaman yang diberikan bukan saja kepada negara tetapi juga pada tingkat individu atau human security. 


\section{Drugs Trafficking}

Menurut United Nations Office on Drugs and Crime (UNODC, n.d): "Drugs Trafficking is a global illicit trade involving the cultivation, manufacture, distribution and sale of substances which are subject to drug prohibition laws". Hal ini berarti bahwa persoalan drugs trafficking atau perdagangan narkoba bukan hanya terbatas pada jual beli semata, namun mencakup penanaman, pengolahan, pendistribusian serta penjualan zat-zat yang dilarang oleh hukum secara global.

Secara lebih spesifik, masalah drugs trafficking dibagi menjadi tiga bagian yang saling terkait antara lain : (1) masalah produksi obat secara ilegal (illicit drug production) meliputi pembudidayaan tanaman yang menjadi bahan baku pembuatan obat-obatan berbahaya seperti tanaman koka sebagai bahan baku kokain, bunga opium sebagai bahan baku heroin dan cannabis atau ganja yang diolah menjadi hashish maupun marijuana; serta pengolahan bahan baku tersebut hingga siap untuk diperdagangkan dan dikonsumsi. (2) perdagangan gelap atau ilegal (illicit trafficking) meliputi segala kegiatan pasca panen maupun pasca pengolahan hingga sampai ke tangan para pengguna, yang meliputi aktifitas pengangkutan, penyelundupan, dan perdagangan obat-obat haram tersebut (3) penyalahgunaan obat-obatan berbahaya (drug abuse) yang merupakan mata rantai terakhir dari masalah narkoba, yaitu penggunaan obat-obatan berbahaya oleh konsumen yang tidak sesuai dengan kaedah kesehatan.

\section{Human Security}

Konsep human security atau keamanan manusia pertama kalinya digunakan dalam Human Development Report tahun 1994 yang dikeluarkan oleh United Nations Development Programme (UNDP). Laporan ini menekankan pemaknaan human security sebagai sesuatu yang universal karena relevan dengan semua manusia dimanapun tanpa mengenal tapal batas negara. Ancaman yang dihadirkan tidak lagi berurusan dengan senjata, namun lebih berurusan pada kehidupan manusia dan martabatnya (UNDP, 1994).

Pada awalnya, konsep ini lebih banyak diidentikkan dengan persoalan militer atau keamanan dari perang/militer. Seiring perkembangan isu-isu global, konsep ini kemudian menghadirkan agenda yang berbeda dan berfokus pada segala hal yang berkaitan dengan kelangsungan hidup manusia dan tidak hanya berfokus pada perang semata. Haq (1995) menyatakan "human security is not a concern with weapons. It is a concern with human dignity. In the last analysis, it is a child who did not die, a disease that did not spread, an ethnic tension that did not explode, a dissident who was not silenced, a human spirit that was not crushed".

Human security memusatkan perhatian pada manusia (people centered) dan bukan negara (state-centereds). Dalam Laporan UNDP (1994) terdapat tujuh skope dari human security, antara lain Economic security, Food security, Health security, Enviromental security, Personal Security, Community security, dan Political security (Acharya, 2007:492). Konsep ini juga mengidentifikasi enam macam ancaman terhadap human security yaitu : pertumbuhan penduduk yang tak terkendali, disparitas peluang-peluang ekonomi, tekanan migrasi penduduk, degradasi 
lingkungan, perdagangan narkotika dan terorisme internasional (Acharya \& Smith, 2002).

Persoalan human security saling mempengaruhi satu sama lain, ketika yang satu terancam atau terdegradasi, maka itu berarti degradasi juga bagi yang lainnya. "Human security can no longer be understood in purely military terms. Rather, it must encompass economic development, social justice, enviromental protection, democratization, disarmament, and respect for human rights and the rule of law...moreover, these pillars are interrelated, progress in one area generates progress in another" (Kofi Annan dalam Archaya, 2001). Persoalan human security telah berkembang menjadi isu lintas batas negara, sehingga ancaman terhadap human security tidak hanya menjadi persoalan domestik suatu negara. Diperlukan kerjasama yang intens antara negara maupun antara aktor non negara, baik organisasi, akademisi, individu dan aktor lainnya yang mumpuni dalam persoalan tersebut dalam merumuskan strategi ataupun bertindak dalam mengatasi berbagai persoalan yang mengancam human security baik di tingkat regional maupun internasional.

\section{HASIL DAN PEMBAHASAN}

\section{Dari Asia Tenggara hingga Sulawesi Barat : Modus operandi masuknya Narkoba di Sulawesi Barat}

Pada tahun 2015, Sulawesi Barat menempati ranking ke 16 dari 34 provinsi di Indonesia untuk tingkat prevalensi penggunaan Narkoba dengan angka 1,90\%. Angka ini sangat jauh dari tahun 2008 yang hanya menempati urutan ke 29 dari 34 provinsi. Artinya, terjadi peningkatan yang signifikan terhadap penyalahgunaan narkoba dan serta jumlah narkoba yang beredar di Sulawesi Barat selama rentan waktu tersebut. Di Sulawesi Barat sendiri, sejauh ini tidak ditemukan adanya lahan penanaman, pabrik ataupun kitchen lab di sulawesi barat. Hal ini berarti bahwa narkoba yang beredar di Sulawesi Barat berasal dari luar wilayah Sulawesi Barat.

Ada beberapa jalur yang menjadi pintu utama masuknya narkoba di Sulawesi Barat. Pertama, Narkoba ini secara langsung berasal Malaysia. Dalam beberapa kasus yang terungkap, sebagian besar berasal dari Tawau, wilayah bagian Sabah, Malaysia Timur. Kemudian diselundupkan ke Kalimantan, biasanya melalui nunukan yang terkenal sebagai jalur sutra narkoba. Hal ini tidak mengherankan karena wilayahnya yang berbatasan langsung dengan Malaysia Timur. Dari nunukan, narkoba ini akan di distribusikan ke berbagai daerah, termasuk ke Makassar, ParePare (Sulawesi Selatan) serta ke Sulawesi Barat.

Untuk masuk ke Sulawesi Barat, para pelaku biasanya menggunakan modus operandi berputar dan pola estafet. Jalur berputar digunakan dalam rangka memperluas jaringan peredaran. Jadi narkoba yang masuk ke Sulawesi Barat, tidak semuanya didistribusikan langsung dari Malaysia, ada juga yang harus melewati plot utama seperti Pare-pare. Jadi pola peredarannya : Malaysia (Tawau)-Kalimantan 
(nunukan)-Sulawesi Selatan (Pare-Pare)- Sidrap-Pindrang-Sulawesi Barat. Sering pula dari Pare-Pare secara langsung diedarkan ke wilayah Sulbar.

Di wilayah Sulawesi Barat, fokus utamanya adalah wilayah Kabupaten Polewali Mandar yang berbatasan langsung dengan Sulawesi Selatan (Kab. Pinrang). Tidak mengherankan kemudian, Kabupaten Polewali Mandar menduduki urutan pertama tingkat penyalahgunaan narkoba di Sulawesi Barat, Menyusul Kabupaten Mamuju di urutan kedua.

Selain itu, jalur lain masuknya narkoba di Sulawesi Barat berasal dari Makassar. Narkoba ini berasal dari berbagai sumber, baik di dalam maupun di luar negeri. Narkoba yang masuk di makassar melalui Mode Transportasi Udara dan melalui jalur laut dan didistribusikan melalui transportasi darat. Makasar dan Parepare merupakan pintu masuk utama narkoba di wilayah sulawesi Selatan dan Sulawesi Barat. Makassar dan Parepare diplot sebagai pintu utama jalur masuknya narkoba. Sementara skup peredaran dikendalikan jaringan narkoba berpusat di Kabupaten Sidrap dan Pinrang. Wilayah distribusi utama terbagi di tiga titik. Masingmasing sindikat yang berada di Kota Palopo, Bone dan Pinrang. Untuk peredaran, jaringan Sidrap dan Pinrang berbagi wilayah. Sidrap menguasai jaringan asal Polopo dan Bone. Sementara Pinrang menguasai wilayah peredaran narkoba di Sulawesi Barat. Jalur distribusinya diakui sangat rapi dan terorganisir. Dari Palopo, kemudian disuplai ke sebagian besar daerah Luwu Raya. Sementara jaringan Bone, menyuplai ke daerah tetangga seperti Kabupaten Wajo, Soppeng, Sinjai hingga Bulukumba. Jaringan dan sindikat Bone berbagi wilayah dengan jaringan yang menguasai peredaran narkoba di Makassar. Suplainya ke daerah Gowa, Takalar dan Jeneponto. Sama halnya dengan jaringan Pinrang. Jaringan ini memiliki memiliki skup peredaran terpisah. Mereka lebih bermain ke wilayah Sulbar, meliputi Majene, Polman dan Mamuju (Kadupa, 2016).

Narkoba yang masuk ke Sulawesi Selatan dan Sulawesi Barat, tidak dapat dilihat sebagai bagian yang berdiri sendiri. Sifat kejahatan narkotika yang telah melintasi batas negara, memberikan kemungkinan besar bahwa narkoba di wilayah ini berasal dari luar negeri. Hal ini didasarkan pada beberapa hal, Pertama, Indonesia lebih domain dalam produksi ganja (terutama wilayah aceh) bukan opium yang bisa diolah menjadi morfin dan heroin atau produk turunannya yang lain. Kedua, dalam berbagai kasus, jenis sabu (ATS) yang beredar banyak di Indonesia adalah jenis sabu jaringan golden triangle. Kasus terbaru yang berhasil diungkapkan oleh petugas sebanyak 1 ton shabu dari China pada tanggal 12 juli 2017 di Anyer, Serang Banten. Setelah itu, Aparat Bea Cukai Batam berhasil menggagalkan jenis shabu yang sama senilai 1 ton yang juga berasal dari China di perairan Bintan Batam dengan menggunakan kapal Wanderlust (kapal Pesiar) berbendera Sierra Leone. Sindikat ini (Sindikat Taiwan), diduga masih merupakan sindikat yang sama dengan kasus sebelumnya yang ditangkap di Anyer. Modus operandi yang digunakan juga sama, yaitu dikemas ke dalam kotak Teh China, melalui jalur laut dan menggunakan pola estafet, artinya, mengiriman pertama menggunakan kapal besar, kemudian ditengah perjalanan dipindahkan menggunakan perahu karet atau menggunakan kapal nelayan dan selanjutnya diangkut menggunakan mobil setelah 
sampai di pelabuhan. Jenis sabu ini diduga kuat berasal dari dari wilayah golden triangle : Malaysia, Laos dan Myammar. Menurut laporan kabinet China, 90\% obatobatan terlarang di China berasal dari wilayah segitiga emas (Sari, 2015). Selanjutnya dari wilayah ini, akan di ekspor ke beberapa wilayah di Indonesia yang minim keamanan dan selanjutnya didistribusikan secara luas ke berbagai wilayah kota, kabupaten hingga pedesaan.

Pada 22 Agustus 2017, Polisi menggagalkan peredaran narkotika jenis shabu seberat 2 kilogram, shabu ini juga dikemas ke dalam teh hijau Merk Guan Yin Wang yang merupakan produk asal china. Shabu ini didelivery dengan tujuan Makasar, Sulawesi Selatan. Kurir yang digunakan juga merupakan warga asal kabupaten Bone, Sulawesi Selatan. Shabu yang ditemukan mirip dengan shabu yang diamankan sebanyak satu ton di Anyer, serang Banten pada Juli 2017 lalu. Kemungkinan besar terjadi perubahan jalur pengiriman melalui kabupaten Nunukan karena wilayah barat yang dianggap tidak aman lagi (Yuniardi, 2017). Dari berbagai kasus ini, dapat disimpulkan, bahwa sebagian besar shabu yag dominan di wilayah Indonesia pada umumnya dan di sulawesi barat merupakan shabu berasal dari dalam negeri dan didominasi dari luar negeri khususnya dari wilayah golden triangle. Pola distribusi yang digunakan para oknum menggunakan alur berputar dan sering berganti alur atau arah, hal ini kemungkinan besar dengan tujuan mengelabui petugas dan mencari wilayah yang aman atau minim kontrol petugas.

Intinya, pola distribusi masuknya narkoba di sulawesi barat bervariasi, namun plot pintu masuk yang utama adalah Makassar dan Pare serta pelabuhan kecil di Sulawesi Barat. Terdapat distribusi langsung dari malaysia ke Sulawesi Barat, meski bukan dalam jumlah yang sangat besar, namun harus tetap mendapatkan perhatian yang serius dari pemerintah. 22 Juni 2017, Polair Polda SulSel berkoordinasi dengan Kapolres Majene, sulawesi Barat berhasil menangkap Silahuddin (warga Majene) di Hotel Davina, Mejene yang membawa 966, 1471 gram shabu yang berasal dari Tawau Malaysia. Menuurt penuturan Kapolda Sulses Irjen Muktiono, bahwa sabu yang diamanakan ini kualitas paling bagus di Tawau, Malaysia. 1 gram dapat dikonsumsi oleh 10 orang. Jadi dalam $1 \mathrm{~kg}$ sabu bisa merusak 10 ribu orang (Muktiono dalam Abdurrahman, 2017).

\section{Perkembangan narkoba di Sulawesi Barat: Sulawesi Barat Darurat Narkoba}

Pada tahun 2015, BNN-Puslitkes UI merilis sebuah data dalam laporan tahunan 2015 dimana Provinsi Sulawesi Barat menduduki peringkat ke 16 tingkat prevalensi penyalahguna narkoba dari 34 Provinsi di Indonesia. Sebelumnya, pada tahun 2014 posisi Sulawesi Barat jauh lebih terpuruk karena berada di rangking ke 11 dalam tingkat penyalahgunaan narkoba. Kondisi ini begitu miris jika dilihat dengan kondisi wilayah yang masih merupakan provinsi baru di Pulau Sulawesi. Jika dibandingkan dengan provinsi lain di Indonesia, posisi Sulawesi Barat yang termasuk kategori tinggi untuk tingkat penyalahgunaan narkoba, sangat berbanding terbalik dengan wilayah lain pada umumnya berada pada posisi teratas. Kecendrungan wilayah yang riskan akan penyalahgunaan narkoba yang tinggi adalah wilayah perkotaan dengan tingkat kesejahteraan penduduk yang tinggi dan gaya hidup 
metropolis. Berbeda jauh dengan wilayah Sulawesi Barat yang masih dalam proses menuju atau penataan wilayah yang lebih baik.

Tabel 1

Penyalahgunaan Narkoba di Sulawesi Barat

\begin{tabular}{|c|c|c|}
\hline 2008 & Populasi & 588.899 \\
\hline & Penyalahguna & 8.398 \\
\hline & Prevalensi & 1,43 \\
\hline & Rangking & 29 \\
\hline \multirow[t]{4}{*}{2011} & Populasi & 873.288 \\
\hline & Penyalahguna & 15.824 \\
\hline & Prevalensi & 1,81 \\
\hline & Rangking & 16 \\
\hline \multirow[t]{4}{*}{2014} & Populasi & 903.800 \\
\hline & Penyalahguna & 18.887 \\
\hline & Prevalensi & 2,09 \\
\hline & Rangking & 11 \\
\hline \multirow[t]{4}{*}{2015} & Populasi & 921.900 \\
\hline & Penyalahguna & 17.539 \\
\hline & Prevalensi & 1,90 \\
\hline & Rangking & 16 \\
\hline
\end{tabular}

Sumber: Tino, 2017. Materi Penyuluhan P4GN BNNP Sulawesi Barat, diolah dari berbagai sumber laporan Putliskes UI-BNN.

Dari data tersebut menunjukkan bahwa terjadi peningkatan angka penyalahgunaan narkoba dari tahun 2008 ke tahun 2015. Jumlah penyalahguna 8.398 naik dua kali lipat menjadi 17.539. Mirisnya lagi, untuk peringkat pada tahun 2008 menduduki peringkat ke 29 dan meningkat tajam ditahun 2014 menduduki peringkat ke 11 dari 34 provinsi. Dari total penyalahguna narkoba, sekitar 50,5\% didominasi oleh para Pekerja, baik PNS, BUMN atau Swasta (Puslitkes UI-BNN, 2015).

Beberapa faktor yang dianggap menjadi penyebab meningkatnya penyalahgunaan narkoba di Sulawesi Barat antara lain : Pertama, gencarnya gerakan memerangi narkoba dalam berbagai level, telah memberikan ancaman pada pasar narkoba yang umumnya terdapat di kota-kota besar. Posisi para bandar dan pengedar yang terancam, menjadikan mereka merubah pola peredaran narkoba. Para pengedar mulai mencari pasar baru yang potensial dan aman untuk dijadikan sebagai wilayah peredaran yang baru, salah satunya adalah Sulawesi Barat. Berbagai kondisi internal, baik dari segi geografis, sosial budaya dan perekonomian masyarakat menjadi faktor pendukung kondisi tersebut.

Kedua, Secara geografis, wilayah ini memiliki garis pantai yang panjang dilengkapi dengan banyaknya pelabuhan-pelabuhan antara lain Pelabuhan Tanjung Bakau dan Bone Manjeng di Kabupaten Mamuju Utara, Pelabuhan Bodong-bodong di Mamuju Tengah, Pelabuhan TPI , Ferry dan Belang-belang di Mamuju, pelabuhan Palipi di Majene serta puluhan pelabuhan rakyat (Ditpolair Polda Sulbar, 2017). 
Pelabuhan-pelabuhan ini berpotensi menjadi pintu masuknya narkoba di Sulawesi Barat. Permasalahannya semakin lengkap karena kondisi pelabuhan yang tidak dilengkapi detektor untuk mendeteksi narkoba yang mungkin dibawah oleh penumpang. Pemeriksaan manual akan sangat menghabiskan waktu dan tenaga. Apalagi pada umumnya, dalam perjalanan lewat jalur laut, kondisi penumpang sangat tidak teratur, baik ketika naik maupun turun. Selain kapal penumpang, penggunaan kapal-kapal nelayan penangkap ikan disinyalir turut mengambil peran penting dalam masuknya narkoba di Sulbar. Banyaknya pelabuhan-pelabuhan yang tidak lagi beroperasi serta pelabuhan-pelabuhan tikus memberikan peluang besar bagi para pengedar, 99 persen peredaran narkoba melalui jalur laut (Sutarya, 2017b).

Ketiga, Kondisi beberapa wilayah di Sulawesi Barat yang termasuk daerah pelosok, serta jauh dari jangkauan polsek maupun polres membuat aksi para pelaku semakin genjar karena minimnya kontrol petugas untuk beberapa wilayah pedesaan. Di kabupaten Polewali misalnya, ditemukan adanya salah satu kecamatan yang dijadikan sebagai pusat pemaketan, yaitu menjadikan paket besar menjadi paketpaket atau bungkus kecil untuk selanjutnya siap diedarkan ke konsumen. Kabupaten Polewali bahkan menduduki peringkat pertama tingkat penyalahgunaan narkoba di wilayah Sulawesi Barat dan kemudian disusul oleh Mamuju (Ahmad, 2017).

Keempat, Ditinjau dari aspek sosial-budaya-ekonomi, hal ini tidak terlepas dari posisi Sulawesi Barat sebagai salah satu provinsi baru yang sedang dalam tahap perbaikan dan pembangunan. Perbaikan infrastruktur, pembangunan kantor dan gedung-gedung baru, termasuk pusat perbelanjaan, tempat karaoke, cafe dan maraknya warkop mulai menjamur di wilayah ini. Kondisi ini turut serta merubah gaya hidup masyarakat untuk menyesuaikan kondisi wilayah yang semakin modern. Pola gaya hidup ke arah modernitas. Perubahan gaya hidup modern semakin didukung dengan adanya kecendrungan peningkatan tingkat kesejahteraan dan pendapatan masyarakat di Sulawesi Barat. Wilayah Mamuju, Mamuju Utara dan Mamuju Tengah didominasi oleh para petani kebun sawit dengan tingkat kesejahteraan yang sebagian besar semakin meningkat (Sutarya:2017a).

Gencarnya gerakan peredaran narkoba di Sulawesi Barat tampak pada tingginya prevalensi tingkat laju angka coba pakai tahun 2016 untuk provinsi Sulawesi Barat yaitu 6,78\% (rata-rata nasional 2,12\%). Angka ini menduduki peringkat Pertama dari 34 Provinsi di Indonesia (BNN, 2016:86). Tingginya angka laju coba pakai ini memberikan indikasi bahwa Sulawesi Barat darurat narkoba, angka peredaran narkoba semakin tinggi disertai keinginan masyarakat di Sulawesi Barat untuk mengkonsumsi narkoba, minimal sekali dalam setahun juga sangat tinggi. Hal ini tidak dapat dibiarkan begitu saja. Modus awal dari para pengedar narkoba adalah dimulai dengan coba-coba, sehingga pada akhirnya meningkat menjadi teratur pakai dan bahkan kecanduan.

Di wilayah Sulawesi Barat, modus yang digunakan sebenarnya tidak terlalu variatif, menurut kepala BNNP Sulbar, modus-modus yang digunakan hanya modus biasa seperti menyimpan di dalam tas, di dalam sepatu, di dalam bohlam atau untuk beberapa kasus yang lebih rumit, ada yang memasukkan paketan kecil di dalam ikan 
yang selanjutnya diedarkan seperti layaknya penjual ikan keliling yang menggunakan peti gabus. Hal ini berarti bahwa masuknya narkoba di Sulawesi Barat tergolong cukup mudah. Minimnya kontrol petugas bahkan adanya keterlibatan para oknum aparat, menjadikan peredaran narkoba sangat mudah dilakukan, sehingga tidak membutuhkan berbagai modus dalam mengelabui Aparat.

Keenam, Keterlibatan petugas menjadi ancaman nyata yang harus dihadapi oleh Pemerintah Sulawesi Barat. Keterlibatan oknum aparat penegak hukum menjadi masalah yang krusial. Menurut data yang dilancir oleh MNC Media, bahwa pada tahun 2016, terdapat puluhan oknum aparat yang terlibat dalam penyalahgunaan narkoba. November 2016, menurut pengakuan Kapolres Mamuju Utara AKBP Yanwar Widyanto, terdapat 21 bawahannya positif menggunakan narkoba. Sedangkan pada November 2016, berdasarkan tes urin yang dilaksanakan oleh Polda Sulbar untuk resort Mamuju, terdapat 40 orang aparat resort Mamuju yang positif menggunakan Narkoba. Pada 2 Mei 2017, dilakukan penangkapan terhadap 4 oknum aparat dari Polda Sulbar yang melakukan pesta sabu bersama 4 warga sipil lainnya. Mirisnya, bahwa para oknum aparat tidak hanya berperan sebagai pemakai, namun juga sebagai bandar dan pengedar kelas kakap (RCTI Sulbar, 2017).

\section{Upaya dan Akibat : Sinergitas Pemerintah dalam mengatasi penyalahgunaan narkoba di Sulawesi Barat.}

Untuk mengatasi persoalan narkoba di Sulawesi Barat, berbagai hal telah diupayakan oleh pihak yang berwenang. Secara khusus oleh pihak BNN adalah melakukan tes urin dimulai dari BNNP Sulbar. Menurut Kepala BNNP Sulbar, bahwa untuk memberantas narkoba harus dimulai dari pihak yang akan memberantas. Selanjutnya melakukan tes urin di institusi kepolisian dan instansi lain, baik yang secara langsung meminta pihak BNN untuk melakukan tes urin ataupun tidak. Persoalannya kemudian, kendala yang dihadapi adalah minimnya biaya dan kurangnya personil yang dimiliki oleh Pihak BNN untuk melakukan identifikasi menyeluruh terhadap semua instansi melalui tes urin yang biayanya tidak sedikit.

Pihak BNNP Sulbar, dengan melibatkan organisasi kemasyarakatan (LSM) melakukan diseminasi informasi P4GN (pencegahan, pemberantasan, penyalahgunaan dan peredaran gelap narkoba) kepada Kelompok Masyarakat, termasuk kepada kepala sekolah dan guru-guru SMP/SMA sederajat dengan tujuan untuk mensinergikan setiap elemen bangsa dalam upaya pencegahan peredaran narkoba (Sutarya, 2017c). Program P4GN tersebut dilaksanakan secara terkoordinasi dan kerjasama sektor instansi dengan harapan; pertama, meningkatkan daya tangkap masyarakat terhadap penyalahgunaan narkoba dan mewujudkan kemandirian masyarakat serta stakeholder berpartisipasi dalam pelaksanaan P4GN agar masyarakat tidka terlibar dalam peredaran gelap narkoba; kedua, meningkatkan pemulihan mantan penyalahguna dan pecandu narkoba agar tidak kambuh lagi; ketiga, melemahkan atau memutus aktifitas jaringan sindikat peredaran gelap narkoba; keempat, meningkatkan produk dan pelayanan hukum serta kerjasama sektoral dalam melaksanakan P4GN (Farid, 2017). 
Hal lain yang harus ditempuh dari segi hukum adalah memberikan hukuman yang dapat menimbulkan efek jera kepada pelakunya, terutama kepada para aparat atau oknum kepolisian yang terlibat. Dalam kasus yang digambarkan sebelumnya, ternyata para oknum yang terlibat hanya mendapatkan pembinaan di markas brimop Sulbar. Hal inilah yang salah satunya menjadikan para pelaku masih setia melakukan aksinya.

Penyalahgunaan narkoba pada dasarnya muncul ketika terdapat supply dan demand - permintaan dan penawaran. Jadi untuk mengatasinya harus pula melalui penekanan terhadap permintaan dan penawaran tersebut. Ketika fokus penyelesaian masalah hanya perfokus pada masalah permintaan (demand) dalam hal ini konsumen, maka dengan sangat mudah para supplier (penyedia) akan segera mencari konsumen yang baru. Demikian juga sebaliknya, ketika yang ditekan adalah persediaan (supply), maka akan bermunculan bandar-bandar dan pengedar baru karena tetap adanya permintaan dari konsumen. Untuk itu, untuk mengatasi hal tersebut, sesuai dengan ASEAN Drug Free, penekanan harus dilakukan dari sisi supply dan demand secara seimbang.

Persoalan narkotika masih menyisakan banyak persoalan. Selain dampaknya yang dapat merusak kesehatan dan mengancam keberlangsungan masa depan generasi, model kejahatan ini juga selalu berkaitan dengan kejahatan transnasional lainnya, seperti terorisme, human trafficking dan pencucian uang. Untuk itu, diperlukan keseriusan dan komitment yang nyata dalam tindakan untuk memerangi narkoba baik di tingkat internasional, regional maupun di wilayah pedesaan. Selain itu, sinergi antara semua elemen untuk bekerjasama menekan supply dan demand secara seimbang dari penyalahgunaan narkoba ini tentunya sangat dibutuhkan untuk mencapai efektifitas dalam upaya memerangi narkoba.

\section{KESIMPULAN}

Kejahatan transnasional peredaran dan penyalahgunaan narkoba merupakan ancaman nyata bagi negara dan keamanan manusia, tidak terkecuali bagi Sulawesi Barat. Dampaknya menyentuh semua dimensi kehidupan manusia, dari kesehatan, ekonomi, sosial hingga persoalan politik, keamanan dan kedaulatan negara. Kecendrungan peningkatan peredaran dan penyalahgunaan narkoba di Sulawesi Barat memberikan pekerjaan rumah yang tiada henti kepada segenap pemerintah, stake holder, BNN hingga Polda Sulawesi Barat untuk extra bekerja sama menangani masalah tersebut. Meski demikian, dibutuhkan peran semua elemen, termasuk masyarakat untuk mengambil perannya sesuai kapasitasnya masingmasing. Membentengi diri sendiri dan keluarga adalah langkah awal yang efektif untuk memerangi narkoba. 


\section{REFERENCE}

Abdurrahman, Muhammad Nur. 2017. Polair P olda Sulsel sita $1 \mathrm{~kg}$ sabu dari pengedar lintas pulau, dalam https://m.detik.com/news/berita/d-3540710/polairpolda-sulsel-sita-1-kg-sabu-dari-pengedar-lintas-pulau, diakses 3 Oktober 2017.

Amitav, Acharya, 2007. Human Security, dalam www.amitavacharya.comdefault>files, diakses 3 Mei 2017.

Acharya, Amitav \& Steve Smith. 2002. The concept of security before and after September 11. Institute of Defence and Strategic Studies, Singapore.

BNN. 2016. Laporan Kinerja Badan Narkotika Nasional Tahun 2016.

Ditpolair Polda Sulbar 2017. Pelabuhan-pelabuhan di Sulawesi Barat, dalam https://www.google.com/amp/www.ditpolairpoldasulbar.com/2017/02/27/Pelab uhan-pelabuhan-di-sulawesi-barat/amp/?espv=1, diakses 21 Agustus 2017.

Farid. 2017. 17 persen penduduk Sulbar teridentifikasi penyalahgunaan narkoba, dalam http://humassulbarprov.id/2017/03/17-persen-penduduk-sulbarteridentifikasi-penyalahgunaan-narkoba/, diakses 17 September 2017.

Mattulada, Thamrin. 2017. Dinamika Politik Pembentukan Provinsi Sulawesi Barat. Pustaka Sawerigading, Makassar.

Al Araf \& Anton Ali Abbas, et al. 2008. TNI-POLRI di masa perubahan Politik. Program Magister Studi Pertahanan Institut Teknologi Bandung, Bandung.

RCTI Sulbar. 2017. Narkoba di Sarang Komandan, dalam http://youtu.be/tkBj8rpch0g, diakses 25 juli 2017.

Roza, Rizki. 2012. Peran Penting Parlemen dalam mencapai Drug Free ASEAN 2015. Info Singkat hubungan Internasional Vol IV, No.14/II/P3DI/Juli/2012. Hal. 6.

Kadupa, Joni. 2016. Ini peta wilayah Peredaran Narkoba di Sulsel. Bupatinya teribat gak ya?, dalam http://kabaroke.com/ini-peta-wilayah-peredaran-narkoba-disulsel-bupatinya-teribat-gak-ya/, diakses 29 September 2017.

Paripurna, Garda T. 2008. Sekilas tentang kejahatan transnasional. Riset Hukum Kejahatan Transnasional, Jakarta.

Sari, Amanda Puspita. 2015. Lebih dari 90\% Narkotika di China berasal dari segitiga Emas, dalam https://m.cnnindonesia.com/internasional/20150624173244-11362155/lebih-dari-90-narkotika-di-china-berasal-dari-segitiga-emas/, diakses 10 oktober 2017.

Sutarya, Dedi. 2017b. 17 Persen penduduk Sulbar teridentifikasi penyalahgunaan narkoba, dalam http://beritakotamakassar.fajar.co.id/berita/2017/03/04/17persen-penduduk-sulbar-teridentifikasi-penyalahgunaan-narkoba/, diakses 30 juli 2017.

Sutarya, Dedi. 2017c. Pengguna narkoba di Sulbar, Mamuju peringkat 2, dalam http://news.rakyatku.com/read/49300/2017/05/18/pengguna-narkoba-disulbar-mamuju-peringkat-2. Diakses 29 juli 2017.

Tino. 2017. Materi Penyuluhan P4GN BNNP Sulawesi Barat. Diolah dari berbagai laporan Putliskes UI-BNN serta laporan kinerja BNN. BNNP Sulawesi Barat,.Mamuju. 
UNODC. (n.d). Drug Trafficking, dalam www.unodc.org/unodc/en/drug-trafficking/, diakses 20 Agustus 2017.

Wawancara dengan Kombes Dedi Sutarya, Kepala BNNP Sulawesi Barat di Kantor BNN Sulawesi Barat, Mamuju, tanggal 28 Agustus 2017a.

Wawancara dengan Baharuddin Ahmad, Bagian kaur bintur satnarkoba Polres Polewali Mandar, tanggal 28 Agustus 2017.

Yuniardi, Jepri (2017) dalam Kaltim.tribunnews. Nunukan jadi jalur sutra narkoba, sabu $2 \mathrm{~kg}$ diselundupkan dari Tawau, dalam https://www.google.com/amp/kaltim.tribunnews.com/amp/2017/08/23/nunukan -jadi-jalur-sutra-narkoba-sabu-2-kg-diselundupkan-dari-tawau, diakses 4 oktober 2017. 